\title{
ANTAGONISM OF YEASTS TO XANTHOMONAS CAMPESTRIS PV. CAMPESTRIS ON CABBAGE PHYLLOPLANE IN FIELD
}

\author{
Sayonara M.P. Assis'; Rosa L.R. Mariano²*; Sami J. Michereff; Gil Silva²; \\ Elizabeth A.A. Maranhão ${ }^{1}$
}

${ }^{1}$ Empresa Pernambucana de Pesquisa Agropecuária-IPA, Vitória de Santo Antão, PE, Brasil. ${ }^{2}$ Universidade Federal Rural de Pernambuco, Departamento de Agronomia, Área de Fitossanidade, Recife, PE, Brasil

Submitted: September 10, 1997; Returned to authors for corrections: November 04, 1998; Approved: May 13, 1999.

\begin{abstract}
Twenty yeast isolates, obtained from cabbage phylloplane, were evaluated for antagonistic activity against Xanthomonas campestris pv. campestris, in field. Plants of cabbage cv. Midori were pulverized simultaneously with suspensions of antagonists and pathogen. After 10 days, plants were evaluated through percentage of foliar area with lesions. Percentage of disease severity reduction (DSR\%) was also calculated. Yeast isolates LR32, LR42 and LR19 showed, respectively, 72, 75 and 79\% of DSR. These antagonists were tested in seven different application periods in relation to pathogen inoculation ( $\mathrm{T}_{1}=4 \mathrm{~d}$ before; $\mathrm{T}_{2}=$ simultaneously; $\mathrm{T}_{3}=4 \mathrm{~d}$ after; $\mathrm{T}_{4}=4 \mathrm{~d}$ before + simultaneously; $\mathrm{T}_{5}=4 \mathrm{~d}$ after + simultaneously; $\mathrm{T}_{6}=4 \mathrm{~d}$ before $+4 \mathrm{~d}$ after; $\mathrm{T}_{7}=4 \mathrm{~d}$ before + simultaneously $+4 \mathrm{~d}$ after). The highest DSRs were showed by LR42 $(71 \%)$, LR42 (67\%), LR35 (69\%) and LR19 (68\%) in the treatments $\mathrm{T}_{7}, \mathrm{~T}_{4}, \mathrm{~T}_{5}$ and $\mathrm{T}_{6}$, which significantly differed from the others. The same yeast antagonists were also tested for black rot control using different cabbage cultivars (Fuyutoyo, Master-325, Matsukaze, Midori, Sekai I and Red Winner). The DSRs varied from 58 to $61 \%$, and there was no significant difference among cultivars.
\end{abstract}

Key words: Xanthomonas campestris pv. campestris, cabbage, biocontrol, yeasts

\section{INTRODUCTION}

Xanthomonas campestris pv. campestris (Pammel) Dowson (Xcc) causes black rot of crucifers, one of the most destructive diseases of cruciferous crops worldwide. It is present in all crucifer-producing regions where yield and quality losses may be very high (31). Black rot can appear on plants at any growth stage. On young plants, margins of cotyledons turn black and may drop off. On mature leaves, symptoms appear along leaf margins as yellow, V-shaped lesions, with the base of the $\mathrm{V}$ usually directed along a vein. As the lesions expand toward the base of the leaf, the tissue wilts and eventually becomes necrotic. The infection may move down to the vascular tissue of the petiole and spread up or down the stem of the plant and into roots. The presence of black veins in yellow lesions

\footnotetext{
* Corresponding author. Mailing address: Universidade Federal Rural de Pernambuco, Departamento de Agronomia, Área de Fitossanidade, Dois Irmãos. CEP 52071-900, Recife, PE, Brasil. E-mail: rmariano@truenet.com.br
} 
along leaf margins is diagnostic of black rot (13). Disease control usually consists of using resistant cultivars, certified seeds, hot-water treatment of seeds followed by application of antibiotics or protectant fungicides, crop rotation, control of weeds and insects, and destruction of infected plants and debris in the field $(13,24)$. Nowadays, the use of resistant cultivars is the most economical method of control.

In addition, several microbial antagonists have been studied to improve control alternatives $(1,6)$. The use of yeasts as control agents of plant diseases is a strategy with great potential $(11,18,20,21,28)$, mainly because of their ability to compete for nutrients $(5,9)$ and colonization sites $(22)$.

Despite some research on the biological control of $X$. campestris pathovars in citrus $(25,19)$, clusterbean $(26)$, cotton $(30)$, mungbean $(8,15)$ rice (14), and soybean (29), very little information exists on the biocontrol of black rot in crucifers $(2,3,4)$. This work aims to study the potential of yeasts to control black rot on cabbage (Brassica oleracea var. capitata L.) in field.

\section{MATERIALS AND METHODS}

\section{Yeast isolates}

The epiphytic yeast isolates used in this study were obtained from leaves of cabbage collected from three nurseries in the State of Pernambuco, Brazil. From each plant, samples with five leaves were randomly taken. A total of 15 plants were sampled per nursery. The isolation followed the methodology of Melo et al. (20) with modifications. Ten discs of $12 \mathrm{~mm}$ diameter were removed per leaf, placed in a tube containing $10 \mathrm{ml}$ of sterile tap water (STW), and sonicated for $10 \mathrm{~min}$. Serial dilutions were made in STW and aliquots $(0.1 \mathrm{ml})$ were plated on potatodextrose-agar medium (PDA) supplemented with $250 \mathrm{mg} . \mathrm{L}^{-1}$ tetracycline. Plates were incubated for $48 \mathrm{~h}$ at $25^{\circ} \mathrm{C}$, and one representative of each yeast colony morphology was transferred to a fresh PDA plate to obtain pure cultures, which were stored on the same medium at $4^{\circ} \mathrm{C}$. Suspensions of antagonist yeast candidates were prepared in sterile distilled water (SDW) using 48 hour-old culture grown at $25^{\circ} \mathrm{C}$ on PDA $(0.05 \%$ Tween 80 was added to the suspension).

The pathogen strain was obtained from the Bacterial Collection of Plant Bacteriology Laboratory, Agronomy Department/Federal Rural University of Pernambuco. Bacterial suspensions $\left(10^{8}\right.$ CFU.ml $\left.{ }^{-1}\right)$ were prepared in SDW using 48 hourold culture grown at $30^{\circ} \mathrm{C}$ on NYDA medium (27).

\section{Preliminary screening of yeast antagonistic to cabbage black rot}

Twenty epiphytic yeast isolates were tested for their ability to reduce the severity of cabbage black rot under field conditions.

Seven week-old cabbage plants (cv. Midori) were simultaneously treated with antagonist candidates $\left(10^{6}\right.$ cell. $\left.\mathrm{ml}^{-1}\right)$ and inoculated with Xcc suspension $\left(10^{8}\right.$ CFU. $\left.\mathrm{ml}^{-1}\right)$. Sprays were performed until runoff. Controls were inoculated with Xcc but not treated with yeasts. Field conditions at the time of the inoculation were: temperature at $32 \pm 2^{\circ} \mathrm{C}$ and $87 \pm 3 \%$ of relative humidity.

The percentage of disease severity (DS\%) was evaluated 10 days after inoculation by estimating the percentage of leafs with lesions areas. The percentage of disease severity reduction (DSR \%) was calculated according to Edginton et al. $(10)$ : DSR $(\%)=[(\mathrm{DSc}-$ $\mathrm{DSt}) / \mathrm{DSc})] \times 100$, where $\mathrm{DSc}=$ leaf area with lesions on the control plants and $\mathrm{DSt}=$ leaf area with lesions on the treated plants.

\section{Influence of the application period of antagonistic yeasts on the control of cabbage black rot}

In order to determine the optimum time for application of the antagonist, the four best black rot biocontrol agents were selected and tested as in the previous trial. Antagonist cell suspensions $\left(10^{6}\right.$ cell. $\mathrm{ml}^{-1}$ ) were sprayed at seven different periods in relation to inoculation with the pathogen suspension $\left(10^{8}\right.$ CFU. $\left.\mathrm{ml}^{-1}\right)$. The treatments were: $\mathrm{T}_{1}=4$ days before; $\mathrm{T}_{2}=$ simultaneously; $\mathrm{T}_{3}=4$ days after; $\mathrm{T}_{4}=4$ days before and simultaneously; $\mathrm{T}_{5}=4$ days after and simultaneously; $\mathrm{T}_{6}=4$ days before and 4 days after; $\mathrm{T}_{7}=4$ days before, simultaneously and 4 days after.

\section{Influence of the cabbage cultivar on the control of black rot by antagonistic yeasts}

The four best black rot biocontrol agents were also tested as in previous trials, using six cabbage cultivars: Fuyutoyo, Master-325, Matsukaze, Midori, Sekai I and Red Winner. The concentrations of antagonist and pathogen suspensions were $10^{6}$ cell. $\mathrm{ml}^{-1}$ and $10^{8} \mathrm{CFU} \cdot \mathrm{ml}^{-1}$, respectively.

\section{Statistical Analyses}

In all experiments, four leaves per replicate were 
used. Each treatment was replicated six times. The results were submitted to analysis of variance (ANOVA), and means were compared by Scott-Knott and Tukey's tests $(\mathrm{P}=0.05)$.

\section{RESULTS AND DISCUSSION}

As a result of the isolation procedure, 20 yeast isolates were obtained from cabbage. The low number of yeast isolates shows that plants in field are submitted to a high amount and diversity of pesticides, which reduce the epiphytic population of microorganisms. The same fact was observed by Michereff et al. (23) when studying yam phylloplane populations. According to Ghini (12), alterations on leaf surface and its environment could be caused by application of pesticides, hormones, fertilizers and also by pollution.

In the initial screening, disease severity reduction ranged from 24.2 to $78.6 \%$ for all 20 yeast isolates. Ten isolates had efficiency varying from 24.2 to $35.6 \%$, four from 38.8 to 47.0 , three from 57.7 to 60.2 and three from 72.3 to $78.6 \%$. Among the isolates tested, LR19, LR42 and LR35 showed, respectively, 78.6, 75.5 and $72.3 \%$ of DSR. These data point the viability of using yeasts for Xcc biocontrol. Few complete studies had shown yeast activity against other plant pathogenic bacteria, such as, Erwinia carotovora subsp. carotovora on bell pepper fruits (20) and E. amylovora on pear flowers (21). The success of an antagonist introduced into the phyllosphere is function of many factors including resistance to an adverse environment, microbiota and plant metabolites, migration ability, competition for space, water and nutrients as well as production of lytic enzymes or antibiotics $(1,5,16)$. The resident yeast population has the special ability to compete for nutrients and/or space which enable them to act as biocontrolers (22).

The best period for antagonist application was $\mathrm{T}_{7}$ (4 days before, simultaneously and 4 days after, in relation to inoculation with the pathogen suspension) however without significantly difference from $\mathrm{T}_{4}, \mathrm{~T}_{5}$ and $\mathrm{T}_{6}$. The highest DSRs were showed by LR42 in $\mathrm{T}_{7}$ treatment (71\%), LR42 in $\mathrm{T}_{4}$ treatment (66.7\%), LR35 in $\mathrm{T}_{5}$ treatment (69.5\%) and LR19 in $\mathrm{T}_{6}$ treatment $(68.3 \%)$, which differed from the others (Fig. 1). The good results obtained with the treatments applied before inoculation are in agreement with Boudreau and Andrews (7), Michereff et al. (23) and Reis et al. (28). This possibly means that the antagonists are able to inhibit the pathogen establishment probably by colonizing the infection sites and competing for nutrients $(5,9$, 23).

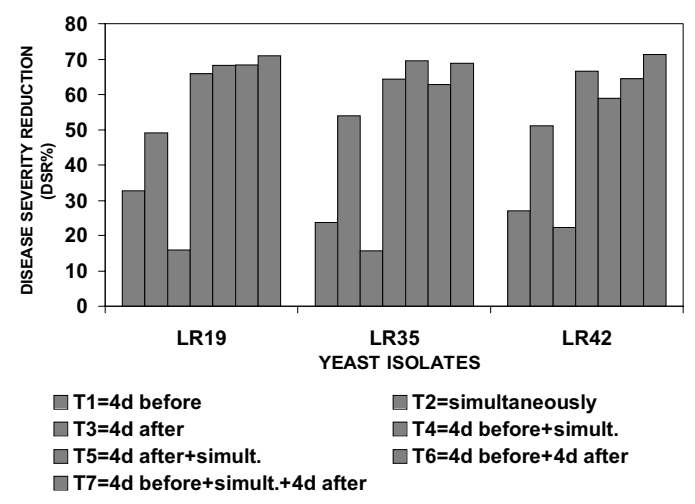

Figure 1: Influence of application period of antagonistic yeasts on the cabbage black rot control.

When the three antagonists were tested against Xcc, using six cabbage cultivars, DSR ranged from 61.3 to $57.9 \%$, without significant difference among cultivars (Fig.2). There was high uniformity among the reaction of the cultivars to Xcc and also to the treatment with antagonists. These cultivars are Japanese hybrids and two of them, "Midori" and "Fuyutoyo", are the most frequent in Pernambuco.

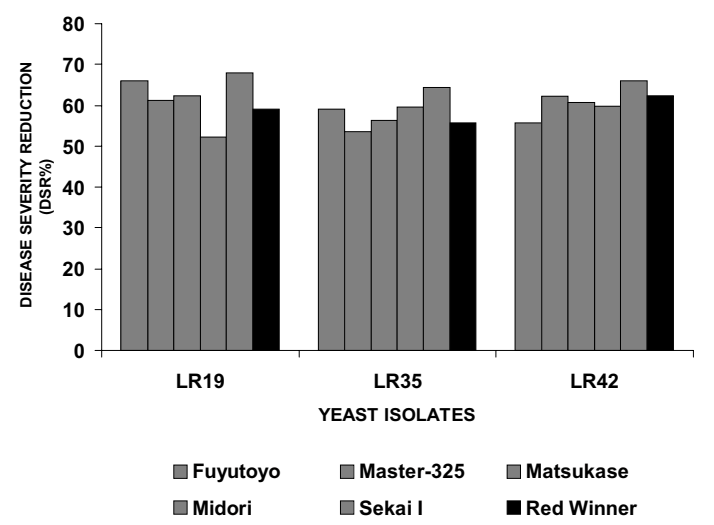

Figure 2: Influence of cabbage cultivar on the black rot control by antagonistic yeasts.

As conclusion, one can say that an integrated control program for the black rot should include resistant cultivar, besides biological control and cultural practices. In the biological control, yeasts should be used due to their efficient mechanisms such 
as competition for nutrients and infection sites and, furthermore, because they are easy to grow and formulate.

\section{ACKNOWLEDGEMENTS}

Authors express gratitude to Agroceres and Topseed companies for supplying cabbage seeds. Financial support provided by UFRPE/CNPq/ FACEPE/FUNDAÇÃO BANCO DO BRASIL

\section{RESUMO}

\section{Antagonismo de leveduras a Xanthomonas campestris pv. campestris no filoplano de repolho em condições de campo}

Vinte isolados de leveduras, obtidos a partir do filoplano de repolho foram avaliados pela atividade antagônica contra Xanthomonas campestris pv. campestris, em condições de campo. Plantas de repolho cv. Midori foram pulverizadas simultaneamente com suspensões do antagonista e do patógeno. Após 10 dias, as plantas foram avaliadas através da porcentagem de área foliar infectada. A porcentagem de redução da severidade da doença (DSR\%), também foi calculada. Os isolados de leveduras LR32, LR42 e LR19 apresentaram, respectivamente, 72,75 e $79 \%$ de DSR. Estes isolados foram testados em sete diferentes períodos de aplicação dos antagonistas em relação a inoculação do patógeno. $\left(\mathrm{T}_{1}=4 \mathrm{~d}\right.$ antes; $\mathrm{T}_{2}=$ simultaneamente; $\mathrm{T}_{3}=4 \mathrm{~d}$ após; $\mathrm{T}_{4}=4 \mathrm{~d}$ antes + simultaneamente; $\mathrm{T}_{5}=4 \mathrm{~d}$ após + simultaneamente; $\mathrm{T}_{6}=4 \mathrm{~d}$ antes $+4 \mathrm{~d}$ após; $\mathrm{T}_{7}=4 \mathrm{~d}$ antes + simultaneamente $+4 \mathrm{~d}$ após). As maiores DSRs foram obtidas por LR42 (67\%), LR35 (69\%) e LR19 $(68 \%)$, respectivamente nos tratamentos $\mathrm{T}_{7}, \mathrm{~T}_{4}, \mathrm{~T}_{5} \mathrm{e}$ $\mathrm{T}_{6}$, que diferiram significativamente dos demais. As melhores estirpes de levedura também foram testadas para controle da podridão negra das crucíferas usando diferentes cultivares de repolho (Fuyutoyo, Master325, Matsukaze, Midori, Sekai I and Red Winner). As DSRs variaram de 61 to $58 \%$, embora não tenha havido diferença significativa entre as cultivares.

Palavras-chave: Xanthomonas campestris pv. campestris, repolho, biocontrole, leveduras.

\section{REFERENCES}

1. Andrews, J.H. Biological control in phyllosphere. Ann. Rev. Phytopathol., 30:603-635. 1992.

2. Assis, S.M.P.; Mariano, R.L.R.; Reis, A.; Silveira, E.B.; Michereff, S.J. Ação de rizobactérias no crescimento de rabanete e no controle biológico da podridão negra e antracnose. Arqu. Biol. Tecnol., 38:843-850. 1995.

3. Assis, S.M.P.; Mariano, R.L.R.; Michereff, S.J.; Coelho, R.S.B. Biocontrol on Xanthomonas campestris pv. campestris on kale with Bacillus spp. and endophytic bacteria. In Advances in Biological Control of Plant Diseases. Eds. Wenhua, T.; Cook, R.J.; Rovira, A., China Agricultural University Press, Beijing, China. 1996a, pp. 347-353.

4. Assis, S.M.P.; Mariano, R.L.R.; Michereff, S.J.; Coelho, R.S.B. Survival and redistribution of Bacillus spp., potential biocontrol agents of black rot, on kale phylloplane. In Advances in Biological Control of Plant Diseases. Eds. Wenhua, T.; Cook, R.J.; Rovira, A., China Agricultural University Press, Beijing, China. 1996b, pp. 375-379.

5. Blackeman, J.P.; Fokkema, N.J. Potencial for biological control of plant diseases on the phylloplane. Ann. Rev. Phytopathol., 20:167-192. 1982.

6. Blackeman J.P., Brown, A.E. and Mercer, P.C. Biological control of plant diseases-present and future trends. Pesqu. Agropecu. Bras., 27: 151-164. 1992.

7. Boudreau, M.A.; Andrews, J.H. Factors influencing antagonism of Chaetomium globosum to Venturia inaequalis; a case study of failed biocontrol. Phytopathology, 77: 14701475. 1987.

8. Bora, L.C.; Gangophyay, S.; Chand, J.N. Biological control of bacterial spot (Xanthomonas campestris pv. cyamopsidis Dye) of mung bean with phylloplane antagonists. Indian $J$. Mycol. Plant Pathol., 23:162-168. 1993.

9. Dik, A. J.; Fokkema, N.J.; van Pelt J.A. Consumption of aphid honeydew, a wheat yield reducing factor, by phyllosphere yeasts under field conditions. Neth. J. Plant Pathol., 97:209232. 1991

10. Edgington, L.V.; Khew, K.L.; Barron, G.L. Fungitoxic spectrum of benzimidazole compounds. Phytopathology, 61:42-44. 1971.

11. Elad, Y.; Köhl, J.; Fokkema, N.J. Control of infection and sporulation of Botrytis cynerea on bean and tomato by saprophytic yeasts. Phytopathology, 84:1193-1200. 1994.

12. Ghini, R. Efeito de fungicidas sobre microrganismos não alvo. Summa Phytopathol., 19:62-63. 1991.

13. Hildebrand, P.D. Black rot. In Diseases and pests of vegetable crops in canada: an illustraded compendium. Eds. Howard, R.J.; Garland, J.A.; Seaman, W.L., The Canadian Phytopathological Society and The Entomological Society of Canada, Ottawa. 1994, pp. 93-94.

14. Hsieh, S.P.Y.; Buddennhagen, I.W. Interactions between Xanthomonas oryzae and saprophytic bacteria isolated from rice leaves. Phytopathology, 61:1321. 1971.

15. Jindall, K.K.; Thind, B.S. Biological control of bacterial blight of cowpea (Vigna unguiculata (L.) Walp.). Phytopathol. Mediterr., 32:193-200. 1993.

16. Leben, C. Epiphytic microorganisms in relation to plant disease. Ann. Rev. Phytopathol., 3:209-230. 1965.

17. Lindow, S.E. Determinants of epiphytic fitness in bacteria In Microbial ecology of leaves. Eds. Andrews, J.H.; Hirano, S.S., Springer-Verlag, New York. 1991, pp. 295-314.

18. Luz, W.C. Efeito dos microrganismos do filoplano sobre manchas foliares do trigo. Fitopatol. Bras., 10:79-84. 1985.

19. Masroor, M.K.; Chandra, S. Antagonism between Aspergillus spp. and Xanthomonas campestris pv. citri (Hasse) Dye, incitant of citrus canker. Nat. Acad. Sci. Lett., 10:233-236. 1987. 
20. Melo, R.A.G.; Mariano, R.L.R.; Michereff, S.J. Controle biológico da podridão mole do pimentão (Capsicum annuum) causada por Erwinia carotovora subsp. carotovora. Summa Phytopathol., 21:206-212. 1995.

21. Mercier, J.; Lindow, S.E. A method involving ice nucleation for the identification of microorganisms antagonistic to Erwinia amylovora on pear flowers. Phytopathology, 86:940945. 1996.

22. Michereff, S.J.; Silva, J.B.; Silveira, N.S.S.; Pedrosa, R.A.; Mariano, R.L.R.; Tavares, L.A.; Tavares, S.C.C.H. Biocontrole pós-colheita da podridão de Lasiodiplodia em frutos de manga por leveduras saprofíticas. Arqu. Biol. Tecnol., 40:29-37. 1997.

23. Michereff, S.J.; Silveira, N.S.S.; Reis, A.; Mariano, R.L.R. Epiphytic bacteria antagonistic to Curvularia leaf spot of yam. Microbiol. Ecology, 28:101-110. 1994.

24. O’Brien, R.G.; Diatloff, A.; Persley, D.M. Brassicas (crucifers). In Diseases of vegetable crops. Ed. Persley, D., Brisbane: Queensland Department of Primary Industries. (Information Series QI93024).1994, pp.30-35.

25. Ota, T. Interactions in vitro and in vivo between Xanthomonas campestris pv. citri and antagonistic Pseudomonas sp. Ann. Phytopathol. Soc. JPN, 49:308-315. 1983.
26. Parashar, R.D.; Sindhan, G.S.; Hooda, I. Biological control of bacterial blight (Xanthomonas campestris pv. cyamopsidis) of clusterbean by epiphytes present on leaf surface. Crop Res. 5:551-558. 1992.

27. Pusey, P.L.; Wilson, C.L. Postharvest biological control of stone fruit brown rot by Bacillus subtilis. Plant Dis., 68:753756. 1984.

28. Reis, A.; Azevedo, S.S.; Assis, S.M.P.; Mariano, R.L.R. Screening yeasts isolates for biological control of Bipolaris zeicola leaf spot on corn. In Advances in Biological Control of Plant Diseases. Eds. Wenhua, T.; Cook, R.J.; Rovira, A., China Agricultural University Press, Beijing, China. 1996, pp. 3687-373.

29. Sendin, M.A.P.; Marreroteran, A.; Vieira, R.M.; Barrios, J.G.; Gonzalez, N.M. Control de la pústula bacteriana de la soya con um extracto microbiano. Ciênc. Agric., 40:31-35. 1990.

30. Verma, J.P.; Singh, R.P.; Chowdhury, H.D. Usefulness of phylloplane bacteria in the control of bacterial blight of cotton. Indian Phytopathology, 36: 574-577. 1983.

31. Williams, P.H. Blackrot: A continuing. Plant Dis., 64:736742. 1980. 